\title{
Chapter 15 \\ Subject in Education for the Twenty-First \\ Century: A Discursive Analysis \\ of the Impacts of PISA in Brazil
}

\author{
Márcia Aparecida Amador Mascia
}

\subsection{Introduction}

In Brazil, we have been experiencing a series of discussions related to the performance of basic school students in the external assessments, in areas of Portuguese Language, Mathematics, and Sciences. In a broad sense, the statistics that are publicized by the different systems of external assessments (Prova Brasil, Saeb, Enem, Enade, ${ }^{1}$ PISA, among others) evidence the low performance and skills of the students in all school subjects in different grade levels. To every new result that is publicized, new steps are adopted by the public education systems: the establishment and increase of extra classes; the production and distribution of pedagogical material; the investment in teacher education; and the bonus to schools and teachers whose students have achieved high rankings in external assessments-like São Paulo and Minas Gerais states_-among others.

As teacher educator in a Graduate Program in Education, I have been receiving distressed teachers, feeling "guilty" for the failure of their students and trying to find new forms of overcoming the "problem." They look for palliative practices in the search of: (1) school materials that can offer better preparation for students in relation to the external assessments, (2) materials that can give subvention for the pedagogical work, and (3) training courses that can give them "recipes" of improving

\footnotetext{
${ }^{1}$ Prova Brasil and Saeb are diagnostics evaluations, in large scale, and they have the aim of testing the quality of the teaching in Brazil. Enem is a test designed to evaluate the skills and performances of students that are finishing high school. ENADE evaluates the performance of the undergraduate students in relation to the content of each area.
}

This article is part of my post-doctoral research developed in the Department of Curriculum and Instruction, University of Wisconsin-Madison (EUA), under the supervision of Professor Thomas S. Popkewitz. It was sponsored by FAPESP.

M. A. A. Mascia ( $\square)$

Graduate Program in Education, Universidade São Francisco, Sao Paulo, SP, Brazil

G. Fan, T. S. Popkewitz (eds.), Handbook of Education Policy Studies,

https://doi.org/10.1007/978-981-13-8343-4_15 
the performance of their students in external tests. The assessments themselves are not problematized; their logic, their rationality, or even, the content of the tests is not questioned, neither are the conflicts between what is taught and what is evaluated in the tests. The relevance of these external tests when compared to the tests and autoevaluations of the students is not questioned, neither is the kind of teacher and student that are idealized and, we can also say, ultimately, "fabricated" a posteriori by the tests.

Taking into account this "scenario," this chapter has the aim of problematizing the contemporary discourses of external assessments in education from a postcritical perspective. Limiting our scope of research to the discourse of PISA, we propose to answer the following research questions: (a) What are the effects of meaning, regarding the constitution of subjectivity in education in Brazil which emerge from the discourse of external assessment-PISA? (b) To what extent the discourses of contemporary external assessment-PISA — establish "new" regime of truth in regarding to the status of the subject in education in Brazil? (c) How do such discourses act as new forms of governmentality in education, while discursive practices of tension between success/failure?

The corpus consists of the discourses that cross the documents of PISAProgramme for International Student Assessment-disposed on the website of the Organization for Economic Cooperation and Development (OECD) and on the website of the Instituto Nacional de Estudos e Pesquisas Educacionais Anísio Teixeira (INEP) in Brazil.

My intention is to pursue the foundations of some of the naturalized concepts in these assessments, from which I hypothesize that the discourse of equality is at the basis of our current education, but at the same time that it proposes equality, the educational policies that are behind naturalize the dichotomies of inclusion/exclusion, success/failure, uniformity/diversity, right/wrong, developed/underdeveloped, and productive/nonproductive. This investigation does not discuss what works/does not work in education in relation to PISA discourse, but how the discourses involving external assessments create a system of reasoning of success/failure in education in Brazil and worldwide.

This chapter has two sections: the first section presents an account of the methodological framework, that is, the postcritical perspective in which we develop the main concepts of Discourse Analysis and the conditions of production, the macrodiscourse. The second section is devoted to the discursive analysis, followed by the conclusions.

\subsection{Methodology and Macro-Discourse}

In this section, we explain the methodological framework, the Discourse Analysis, and bring the macro-discourse, that is, the geographical, social, and historical context of the research, Brazil, and provide a brief description of PISA. 
Discourse analysis methodology requires the examination of the geographicalsocial-historical context within which the discourse is constructed followed by a microanalysis of the texts. The description of the geographical-social-historical context, also understood as "conditions of production," aims putting the social representations of the corpus, PISA discourse, in this case, into focus, as well as the place occupied by the subjects in this discourse. After contextualizing the production of a certain discourse, the analyst concentrates on the properties of the discourse. Discourse is characterized as possessing constitutive heterogeneity, which implies that doing discourse analysis is fundamentally trying to find the interdiscourses that are at the interior of a certain discourse. We understand discourse as discursive practices in Foucault's terms, as follows:

(...) a body of anonymous, historical rules, always determined in the time and space that have defined a given period, and for a given social, economic, or linguistic area, the conditions of operation of the enunciative function. (Foucault 1972: 117)

Thus, discursive practices are related to rules that establish or authorize our discourses in relation to the thematic choices, to the acceptable objects, and to the acceptable enunciative modalities by the subject. That is, discourse is not the linguistic manifestation, but the conditions upon which some linguistic manifestations are possible while others are not. We cannot say whatever we want, the way we want and for whom we want. We are "obliged" (even though we do not know it, as these rules that oblige us are anonymous, erased, camouflaged and so camouflaged that we believe that we are autonomous, that we choose our sayings) to speak in a certain way, to certain subjects, and using certain authorized content. This is the concept of discourse within which we intend to work.

Let us add another concept to our repertoire, the subject, which can be understood as an effect of discourse, as a position occupied by the "individuals" in the discourse. The viewing of the subject as "effect of discourse" comes from Pêcheux and Fuchs (1975) when they talk about the two illusions (or forgetfulness) in which the subject and meaning are inscribed: the illusion of the origin of discourse and the illusion of only one meaning. For the first, we forget that our words are not original; when we talk, we inscribe our discourse within certain rules; and for the second, we forget that what we are saying will be interpreted, so it can be interpreted in different ways, that is, it does not have only one meaning. These two illusions affect the discourse. From this perspective, the subject can be considered decentered, historical, and affected by history; incapable of "consciously" transforms the world, he/ she can provoke changes, but does not have control over the meanings of these changes.

For its side, any discourse takes part in some "discursive formations," and it is inside these discursive formations that the meanings are defined as acceptable or not. Our meanings are not conceived by ourselves, as we think or desire. When we talk, we are not only "communicating" but also saying which discursive formations we belong to.

Ultimately, for Foucault and for us, in this research, discourse is taken as a practice, a discursive practice, and subject is taken as effect in these practices. As a 
result, any social practice is a discourse, understood as a discourse in a broad sense. The discourse of PISA will be analyzed within these two concepts: of discourse and of subject.

The macro-discourse, or the conditions of production of our corpus, PISA discourse, involves the geographical, social, and historical moment related to the years that precede the implementation of the external assessments, like PISA, both in the world and Brazil.

In geographical terms, Brazil is a huge country, with 26 states, and it is the largest country in South America and the world's fifth largest country, both by geographical area and by population with over 192 million people. It is the only Portuguese-speaking country in the Americas and the largest lusophone country in the world. It is divided into five regions: south, southeast, north, northeast, and central west. The differences that characterize these regions are not only based on the geography. Besides being geographically different, we can point social cultural differences, especially in relation to the distribution of the wealth. While people in the south and southeast are richer, people in the north, northeast, and central west are not. But even the richer regions present visibly two poles: extremely rich people and miserable ones, living in the same cities, especially in the metropolis, like São Paulo and Rio de Janeiro. In spite of living in the same city, they live in two opposite ways: in luxury and in misery, oppositions that will be seen in the results of PISA, for example.

In the political sphere, Brazil, at the end of the twentieth century, undertook a process of political opening, with the fall of the military dictatorship leading to the proliferation of political parties, particularly the left-socialist party, PT (Partido dos Trabalhadores, Worker's Party). At the same time, as soon as the civilians rose to power, new alliances were established in order to silence the dictatorship crimes. The crisis in education due to the social inequalities and poor distribution of income, installed during the dictatorship, would not be changed during the reigns of the socalled new republican governors, in spite of the process of the democratization of education promoted by Minister Jarbas Passarinho at the end of the twentieth century. The state governors did start a process of opening new schools, but as soon as the quantity of education was increased, the quality decreased. New schools were built, but the formation of teachers was forgotten.

Within the Worker's party at the power, Luíz Inácio Lula da Silva and Dilma Rousseff, we had an improvement in public education, both of the basic (fundamental and high school) and of the university, during the 13 years from 2003 to 2016, when Dilma suffered an impeachment. In spite of the investment in education during this period, the quality in education is still being questioned as we will see in the excerpts analyzed. During most of these years that Brazil is taking part in PISA, we were under the Worker's Party management.

In global terms, during the last decades of the twentieth century, there was an increasing of scientific and technological (and even cultural) domination by the industrialized countries, mainly the United States. This domination led to the current process of globalization which resulted in a cultural and linguistic domination 
by the first world countries in relation to the emergent ones, like Brazil. ${ }^{2}$ The "ghost" of an excluded country was installed that would affect everyone and everything, including education.

In the context described above, PISA has emerged as a worldwide study by the Organisation for Economic Co-operation and Development (OECD) applied to member and nonmember nations which was first performed in 2000 and then repeated every 3 years. The main goal is providing a worldwide range of information to improve education. But critics, as expressed in the letter to Andreas Schleicher, director of the OECD's PISA, from academics around the world in 2014, have been denouncing that it has really contributed to an escalation in testing and a dramatically increased reliance on quantitative measures. It has begun to deeply influence educational practices in many countries, making an overwhelming changing in the education systems in the hopes of improving their rankings. Another critic is related to the narrow range of measurable aspects of education, that is, biased in favor of the economic role of schools and the preparation of young men and women for gainful employment, on the other hand, disregarding the less measurable or immeasurable educational objectives, like physical, moral, civic, and artistic development, that contribute to prepare students for participation in democratic self-government, moral action, and a life of personal development, growth, and well-being. This way, the letter points, PISA acts in a way to subvert our image of what education is and ought to be about, playing the role of a global arbiter of the means and ends of education around the world.

Taking into account the description of the macro-discourse above, we present the microanalysis. The microanalysis consists of identifying the effects of meanings and pointing how they appear in the linguistic materiality. But the meanings depend on the conditions of production, that is, the geographical-social-historical moment in which they are constructed, as specified in this part.

The analysis of PISA-Brazil discourse enables us to understand the reason upon which some images are constructed and naturalized. According to Chakrabarty, the first world, Europe, "works as a silent referent in historical knowledge" (1992 p. 337), and as great narratives are taken as models, when the emergent countries' histories are written, they are translated in terms of lack, incompleteness, and absence.

The image of incompleteness has been a constant in Brazilian Educational Discourse, especially when applied to public schools, which are always conceived as needing reforms in order to reach the completeness. Curricula reforms are always designed to provide new ideas for teachers and schools that have consistently failed their students.

Next section is dedicated to the discursive analysis.

\footnotetext{
${ }^{2}$ For more details, see Pennycook, A. (1994). The Cultural Politics of English as an International Language. New York, Longman.
} 


\subsection{Analysis: PISA Shaping the Subjects for the Twenty-First Century}

My data consist of the discourse displayed on two websites in relation to Brazilian performance on PISA: http://www.oecd.org/pisa/and http://portal.inep.gov.br/pisa/ sobre-o-pisa. The analysis will focus on some excerpts from these websites.

\subsection{PISA on the OECD Website}

I will start bringing the definition for the Programme for International Student Assessment (PISA) by $\mathrm{OECD}^{3}$ :

(PISA) is a triennial international survey which aims to evaluate education systems worldwide by testing the skills and knowledge of 15-year-old students. To date, ${ }^{4}$ students representing more than 70 economies ${ }^{5}$ have participated in the assessment.

Still, according to the website,

around 510,000 students in 65 economies took part in the PISA 2012 assessment of reading, mathematics and science representing about 28 million 15-year-olds globally. Of those economies, ${ }^{6} 44$ took part in an assessment of creative problem solving and 18 in an assessment of financial literacy. For this year, 2015 assessment, more than 70 economies have signed up to take part in the assessment in 2015 which will focus on science.

I want to call attention to two main discursive materialities that appear here: "economies" instead of using country, people, and "literacy" in relation to the skills that students should show in the school subjects.

These two uses, "economy" and "literacy," are explained on the website as the following:

PISA is unique because it develops tests which are not directly linked to the school curriculum. The tests are designed to assess to what extent students at the end of compulsory

\footnotetext{
${ }^{3}$ The mission of the Organization for Economic Co-operation and Development (OECD) is to promote policies that will improve the economic and social well-being of people around the world. The OECD provides a forum in which governments can work together to share experiences and seek solutions to common problems. We work with governments to understand what drives economic, social, and environmental change. We measure productivity and global flows of trade and investment. We analyze and compare data to predict future trends. We set international standards on a wide range of things, from agriculture and tax to the safety of chemicals. We also look at issues that directly affect everyone's daily life, like how much people pay in taxes and social security, and how much leisure time they can take. We compare how different countries' school systems are readying their young people for modern life, and how different countries' pension systems will look after their citizens in old age. From http://www.oecd.org/about/. Accessed: 03-27-2015.

${ }^{4}$ From http://www.oecd.org/pisa/. Accessed: 03-27-2015.

${ }^{5}$ Bold type by the author.

${ }^{6}$ Bold type by the author.
} 
education can apply their knowledge to real-life situations ${ }^{7}$ and be equipped for full participation in society. The information collected through background questionnaires also provides context which can help analysts interpret the results.

Even though it apparently seems very interesting in a supposedly homogeneous and equal society, we do not live in this imaginary world. The peoples from different countries, different languages, different cultures, different religions, different ethnicities, different colors, different sexualities participate differently in real-life situations and different peoples need different knowledge for full participation in their specific society. These differences are not taken into account by the assessment. Actually, it is considered only the knowledge that is important for those countries or, in other words, those economies that develop and apply the assessment. And, unfortunately, the results are compared using the parameters of wealthy economies and the useful knowledge for them.

The idea and ideal of equality is embedded in the liberal thought which underlies the enlightenment claim of equality of men. Education, which is on the basis of enlightenment, is believed to be the motor to guarantee equality in society.

But, according to Mehta (1997), it has actually been exclusionary, as "Liberal theoretical claims typically tend to be transhistorical, transcultural, and most certainly transracial" (op., cit., p. 63), which means that, "behind the capacities ascribed to all human beings there exists a thicker set of social credentials that constitute the real bases of political inclusion" (op., cit., p. 61), that is, "power relations." Some nations and some cultures, which detect power, are taken as parameters and PISA tests are designed under these parameters to evaluate the whole universe, indicating if the students are or are not prepared to apply their knowledge to real-life situations and to have full participation in society.

In its turn, the idea of literacy to think of school subjects is very fruitful, especially if we consider that literacy is related to what students can do, in real life, with what they have learned in schools, but I question the idea of one math literacy, one science literacy, one financial literacy, or one reading literacy. We should think in literacies, or multiliteracies, in a society that is multiple. For example, for people who live in rural areas, who have their own piece of land, and who make their living from plantation, math or science or even reading knowledge is important, but for them, it probably has some specificities in relation to the environment where they live. In relation to maths in education, there has recently emerged a field of study which is called "ethnomathematics." According to the International Study Group on Ethnomathematics (ISGEm) website:

The term was coined by Ubiratan D'Ambrosio ${ }^{8}$ to describe the mathematical practices of identifiable cultural groups. It is sometimes used specifically for small-scale indigenous societies, but in its broadest sense the "ethno" prefix can refer to any group-national societies, labor communities, religious traditions, professional classes, and so on. Mathematical practices include symbolic systems, spatial designs, practical construction techniques, calculation methods, measurement in time and space, specific ways of reasoning and inferring,

\footnotetext{
${ }^{7}$ Bold type by the author.

${ }^{8}$ Ubiratan D'Ambrosio is a Brazilian professor and researcher.
} 
and other cognitive and material activities which can be translated to formal mathematical representation. ${ }^{9}$

Math literacy can be very different if we take into account the cultural diversity of mathematical practices, so do real-life situations. The notion of ethnomathematics, which was coined by a Brazilian, problematizes the idea of a universal knowledge in mathematics that can be measured by a universal test, like PISA. It incites us to think in a broader way our understanding of knowledge applied to education and evaluation in education.

In the link, "What the assessment involves," we see the following:

Since the year 2000, every three years, fifteen-year-old students from randomly selected schools worldwide take tests in the key subjects: reading, mathematics and science, with a focus on one subject in each year of assessment. In 2012, some economies also participated in the optional assessments of Problem Solving and Financial Literacy. Students take a test that lasts 2 hours. The tests are a mixture of open-ended and multiple-choice questions that are organized in groups based on a passage setting out a real-life situation. ${ }^{10} \mathrm{~A}$ total of about 390 minutes of test items are covered. Students take different combinations of different tests.

I want to call attention to the bold type phrase, "Tests based on a passage setting out a real-life situation." Real-life situation from and for whom? Again, we have the idea (and the ideal) of universality in education, as the discourse erases the subjects that conceive the tests and to whom they are addressed. We can say that these tests do not only measure if the students know how to deal in "real-life situation," but they also produce realities and dictate how education should be organized in a way to prepare students to deal with the so-called real-life situations. They work in a way of "making up people" (Hacking 1986), or better "making up" how schools should function in a way of preparing students for certain situation and not others, disregarding if they are really "real" for them. This way, some situations are considered while others are not, and this contributes, at last instance, for including some people and excluding others. The tests are prepared and applied to reveal exactly how schools erase the specificities of differences around the world and prepare students to confront each other in a competitive market. Education has visibly transformed into competition, which dictates what is a good school, a good teacher, a good student, a good educational policy, a good school curriculum, a good country, or better, a good economy, and so on. Schools, in this rationality, should prepare students for the labor market and the ones that do good in the tests are in, while the others are out, which evidence the tension between inclusion and exclusion in education. This is what Foucault calls as "regime of truth," as "a general politics of truth," and in Foucault's sense, there is a circular relation between truth and power:

Each society has its regime of truth, its general politics of truth-that is- the types of discourse it accepts and makes function as true.

${ }^{9}$ From ISGEm International Study Group on Ethnomathematics. http://isgem.rpi.edu/ Accessed: 05-19-2015.

${ }^{10}$ Bold types made by the author. 
Truth is linked in circular relation with systems of power that produce and sustain it, and to effects of power which induce and which extend it—a regime of truth (Foucault 2000: 131-132)

From such ground, the concept of "regime of truth" can be considered inside the idea of "circularity," proposed by Foucault, between power and knowledge. We can conceive PISA, and the subjects that PISA fabricates, as regime of truth because truth is produced, sustained, valorized, and regulated by a series of mechanisms, techniques, and procedures that work inside institutions, in ordinary life, that at the same time that produces knowledge, it reinforces power. PISA can also be considered as "a regime of truth" because it defines specific mechanisms which produce discourses that function as truth in contemporary time, dictating beliefs, values, and morality. Contemporary societies have centered the discussion of truth on scientific discourse, especially of equality, that is, the ways of including/excluding people in the labor market, which commands not only the production but also the distribution of the knowledge produced. That is why Foucault calls it as circularity, they produce and feed each other.

According to Hacking (1990), one of the mechanisms of circulation of regimes of truth is related to the emergence of statistics which gives stability to the world, making decision more transparent. That is what happens with PISA, as we see below:

In addition, given PISA is an ongoing triennial survey, countries and economies participating in successive surveys can compare their students' performance over time and assess the impact of education policy decisions.

One of the aims of PISA is of shaping the political educational decisions around the world in favor of students showing themselves prepared for the tests. Of course, countries are changing their policies and schools are shaping curriculum to this and other assessment tests, without questioning the tests, or what is behind this worldwide model of constructing education, and subjectivities in education, based on surveys only.

PISA constructs subjectivities in education, as it is understood by Popkewitz:

PISA globally positions the child and nation through a style of thought that differentiates and divides through creating categories of equivalence among countries. The categories of equivalence (or sameness) function as an identity to represent difference. What now needs attention is how numbers do not act alone but act as they are inscribed in a grid of practices that give intelligibility to kinds of people. The "facts" enlisted through PISA's measurements of practical knowledge are not merely descriptive of something "practical." They are assembled historically in a manner that creates a cultural space that shapes and fashions modes of living. (Popkewitz 2011: 36)

This way, we can consider that PISA is not only about grids and numbers but also about subjects in education and about the future inhabitants of the world that are being forged today.

To prepare students for competition, it was prepared "PISA-based test for schools":

As interest in PISA has grown, school and local educators have been wanting to know how their individual schools compare with students and schools in education systems 
worldwide. To address this need, the OECD has developed the PISA-based test for schools. It is currently available in the United States and the OECD is in discussions with governments to make the test available in other countries such as England and Spain.

The website persuades local educators to compare their results with world results. Exactly what I have been discussing, the local knowledge is erased in favor of a worldwide knowledge, that is nothing more than the knowledge based on an ideal situation of schooling, or in Popkewitz's (2011: 39) words, based on “The grid that gives intelligibility to these 'facts' [that] serve as 'a map' for structuring what is to constitute 'experience' and thinking about what is practical and useful." Comparisons through numerical systems erase that a certain kind of knowledge and also "child produced in the alchemy of school is assumed in the assessments" (Popkewitz 2011: 39).

We can also see in the following what is PISA for:

PISA offers insights for education policy and practice, and helps monitor trends in students' acquisition of knowledge and skills across countries and in different demographic subgroups within each country. The findings allow policy makers around the world to gauge the knowledge and skills of students in their own countries in comparison with those in other countries, set policy targets against measurable goals achieved by other education systems, and learn from policies and practices applied elsewhere. ${ }^{11}$

It is a worldwide mechanism of control, dictating policy targets in education, based on tests applied to students and on the quantitative results of these tests. It is implied in this excerpt that what is a succeeded education model for a country should be "imported" and applied to the ones whose education is not being well succeeded. But we question again the parameters to consider what is success and what is not based on "findings" revealed by numbers. According to Popkewitz (2011 31), "the politics of PISA order what children should know and how that knowing is made possible," which culminates, in our view, in setting new policies in local schools dictated by the global findings of the test, that is, the local is being shaped by the global.

Let us see what the Brazilian website presents.

\subsection{PISA on the Brazilian Website}

Brazilian website starts with the following definition:

The Programme for International Student Assessment (PISA) is an initiative of compared evaluation, applied to students within 15 years old, age at which it is presupposed the conclusion of mandatory basic schooling in most countries. The programme is developed and coordinated by the OCDE (Organization for Economic Co-operation and Development). In

\footnotetext{
${ }^{11}$ From "Programme for International Student (PISA) Results from PISA 2012," p. 10. http://www. oecd.org/pisa/keyfindings/pisa-2012-results.htm. Accessed: 05-01-2015.
} 
each participant country there is a national coordination. In Brazil, PISA is coordinated by the Instituto Nacional de Estudos e Pesquisas Educacionais Anísio Teixeira (Inep). ${ }^{12}$

Contrasting with the OECD website, there is not much reference to "countries" as "economies." The excerpt above, which introduces PISA, brings the word "country" twice. Only once the website uses the word "economy," as following:

Participant countries

Nowadays, the 34 OECD countries members and many invited countries participate on Pisa. The results of Pisa 2012 congregated 65 countries, however this total congregate some economies that can't be considered countries, as Hong Kong, Macau, Shanghai and Taiwan. ${ }^{13}$

But, even though using "economy," it is being used as an alternative for "country." This option for "countries" instead of "economies" has the effect of meaning of attenuating the idea of economy and competition that is behind the assessment. The discourse of Brazilian website brings the image that PISA is only related to improvement in education.

I consider that this is because the labor market discourse was not explicit in political issues in Brazil, as the party that was in power at the time when the excerpt was written was the Worker Party and it has a socialist tendency, but Labor Market appears in a camouflaged way. The political situation in Brazil can be best summarized by Fernando Haddad, the Ministry of Education, from 2005 to 2012, when he made an evaluation of PISA 2009. For him,

In Brazil more than 5\% of the GDP is invested in public education, while before less than $4 \%$ was invested. We set a goal in the national education plan that by 2020 , the average salary for a teacher will have to be equivalent to the average salary of other professionals with university level degrees in the country.

This is what the government aims in education, in Brazil, and PISA is among the instruments that supposedly could contribute to improve education, bringing an international parameter. As we can see, in this discourse of progress/improvement, education is the topic, not "economy." It is been a motto in Brazil for a long time; every time, when we talk about improvement in education, we talk about teacher

\footnotetext{
${ }^{12}$ My translation from the original: O Programme for International Student Assessment (Pisa)— Programa Internacional de Avaliação de Estudantes—é uma iniciativa de avaliação comparada, aplicada a estudantes na faixa dos 15 anos, idade em que se pressupõe o término da escolaridade básica obrigatória na maioria dos países. O programa é desenvolvido e coordenado pela Organização para Cooperação e Desenvolvimento Econômico (OCDE). Em cada país participante há uma coordenação nacional. No Brasil, o Pisa é coordenado pelo Instituto Nacional de Estudos e Pesquisas Educacionais Anísio Teixeira (Inep). From http://portal.inep.gov.br/pisa/sobre-o-pisa. Accessed: 03-27-2015.

${ }^{13}$ My translation from the original: Países participantes Atualmente, participam do Pisa os 34 países membros da OCDE e vários países convidados. Os resultados do Pisa 2012 congregaram 65 países, entretanto este total congrega algumas economias que não podem ser consideradas países, como Hong Kong, Macao, Shangai e Taiwan. From http://portal.inep.gov.br/pisa/sobre-o-pisa. Accessed: 03-27-2015.
} 
income, as it is lower if compared to other careers. In relation to PISA, the Ministry of Education continues describing the "dramatic Education situation," as follows:

In the year 2000 we were in a particularly dramatic situation in Brazil. It was the first year of the PISA program, and Brazil did very badly. Because not only had the quality of education fallen dramatically during the previous decade, there was a problem of students dropping out and failing. 2000 was a landmark in Brazilian history because it was the year when we desperately needed to change the situation. ${ }^{14}$

In his discourse, the first PISA test is taken as a landmark for changing in education in Brazil, as if it was necessary an external evaluation to measure our problems. Actually, what PISA does is giving worldwide visibility to our problems, and as part of government, he needs to give an answer. This is very familiar in political discourse of reforms in education in Brazil, as it has already been discussed by Mascia (2009), when analyzing the discourse of curricula reforms in Brazil in the 1980s and 1990s. When the Ministry or the Secretary of Education is instigated to take a position about an issue, he/she promptly comes with an assertive answer of reforms. If we compare the above discourse with the one analyzed about the curricula reforms in the 1980s and 1990s, the only difference is the motivation to an answer, in this case, PISA results. I am arguing that what PISA does is only giving international visibility to the problems we already know, and it does not give a solution. Otherwise, it can mask them, as we will see ahead.

Brazil's struggle for the recovering of the quality in education lies back to 1970s, when we started having a process of political opening, with the falling of the dictatorship and the appearance of many political parties. Unfortunately, the democratization of education meant loss of quality, that is, an increase in the number of schools and a decrease in the quality. This search for quality has meant, along these decades, many discussions: teacher's salary; infrastructure in schools, teacher's education, curricula reforms, and more recently, the bad results in external evaluations, like PISA. The education seems always to be in crisis and every new government or party has a word of salvation in education, as in the above discourse in which we see again the discussion of teacher's salary. It is important to call attention that the political party that was in power at the time of this speech is the Worker Party, and the salary of the workers is always on the agenda.

Another problematization in relation to assessment tests in large scale, like PISA, is the naturalization of differences, not only among countries but also inside the countries, especially those with overwhelming differences like Brazil. Let us take the following excerpts from the booklet called "Country Note-Results from PISA 2012-Brazil key findings," in the item "Resource allocation to advantaged and disadvantaged schools" ${ }^{15}$ :

Brazil must find ways to support socio-economically disadvantaged schools more strongly in order to establish a level playing field for all students.

\footnotetext{
${ }^{14}$ From http://www.oecd.org/pisa/pisaproducts/brazil.

${ }^{15}$ Both found on OECD and INEP websites.
} 
PISA results show a positive relation between the resources invested in education and performance, but only up to a certain point. PISA also shows that at all levels of expenditure, higher-performing countries tend to distribute educational resources more equitably between socio-economically advantaged and disadvantaged schools.

- In Brazil, the schools serving more advantaged students, which include many private schools, have access to better educational resources, better physical infrastructure, and report fewer problems of attracting and retaining qualified teachers.

- In Brazil, about 13\% of 15-year-old students go to a private, independent school. On average, private schools show better performance in PISA. While their students overwhelmingly come from advantaged families, the performance advantage is apparent even after accounting for socio-economic status. For the more affluent families, private schools - which provide access to better educational resources, better physical infrastructure, and have lower student-teacher ratios-are associated with better learning outcomes.

It is clear, in the above excerpt, that best performers in PISA, in Brazil, are the ones that are socioeconomically advantaged, that attend, mainly, private schools with better infrastructure. This makes us raise another problematization to our discussion, the one related to bonus in education. Teachers and staff from high-scored school receive bonus and teachers and staff from average or low-scored school do not, which means that, in a certain way, they are punished. We consider that the absence of bonus can be understood as a certain kind of sanction.

In relation to the bonus, we can see it explicit on the Ministry of Education's words:

Also, we created a mechanism to reward ${ }^{16}$ the schools that achieve their goals, so that schools that meet their objectives automatically receive bonus funding from the federal government. So the schools could assume greater autonomy. ${ }^{17}$

Even though the Ministry asserts in another part of the interview that this mechanism will not penalize or punish the schools and subjects involved-students, teachers, and staff - it is a mechanism of exclusion, and it excludes at the time that some schools are rewarded and others are not. But the main effect is that it is a perverse mechanism, as we consider that it camouflages the "real" problems in education in Brazil, subverting the situation, rewarding, and giving more conditions to the ones that already have them. This rewarding is based on the idea (or ideal) of homogeneity in education, that erases the historical conditions of the knowledge and of the subjects involved, as we have already discussed. This kind of evaluation takes as granted that all schools are equal, so they can compete in the same level, based on numbers and tables that show the ranking, which works in a way of inclusion and exclusion at the same time, using dichotomic categories: right versus wrong; developed versus underdeveloped (or in development); and productivity versus nonproductivity; success versus failure.

In this way, the external evaluations only rank the schools, the educational systems and countries, or better, the economies, cognitively, by the results of the tests, disregarding the context, the social conditions, and the real lives of the subjects

\footnotetext{
${ }^{16}$ Bold types made by the author.

${ }^{17}$ From http://www.oecd.org/pisa/pisaproducts/brazil.
} 
involved in education, teacher, and student. Even though PISA claims that they know the social conditions of each country, when the results are showed in statistics, we only see numbers, not the social conditions of these numbers. It is a mechanism of control inside the apparatus of governmentality, as these tests are applied by external agencies that consider the subjects in education and the knowledge as universal and not historical constructed.

Foucault understands "governmentality" as:

1. The ensemble formed by the institutions, procedures, analyses and reflections, the calculations and tactics that allow the exercise of this very specific albeit complex form of power, which has as its target population, as its principal form of knowledge political economy, and as its essential technical means apparatuses of security.

2. The tendency which, over a long period and throughout the West, has steadily led towards the pre-eminence over all other forms (sovereignty, discipline, etc.) of this type of power which may be termed government, resulting, on the one hand, in formation of a whole series of specific governmental apparatuses, and, on the other, in the development of a whole complex of savoirs (Foucault 1991: 102-103).

PISA can be considered as an "apparatus of security" (Foucault 1991: 48-49), which operates very well on the condition of freedom, as Foucault postulated. Countries are free to choose to take part in PISA, but those which does provide its people a feeling of well-being in economy, politics, and education. On the second part of the definition, governmentality refers to the well-known Foucault's concept of power-knowledge relations, that is, to the Western movement in politics toward a complex bureaucratic society which operates new forms of discipline and that culminates in new knowledge, "savoirs," which, in its turn, generates sovereignty and discipline, that is, power-knowledge relations.

\subsection{Final Remarks}

From this analysis, we tried to bring into light some meanings that are behind the PISA discourse and that contribute to create new rationalities in education, in a way to fabricate the subjects necessary for the new status quo in education and society, especially related to Brazilian context. The analysis points education as being the main locus to transform individuals into moral subjects that current society needs, and this includes the labor market. If education means "docilization" (Foucault 1977 b) in a way to prepare body and mind for the society, this is exactly what PISA does; it fabricates the subjects for the technological society in which we live in, that is, the global citizen.

We agree with Popkewitz (2011: 43) that PISA collaborates for the "double gestures of its pedagogical principles: the hope of the cosmopolitan society that circulates in the notion of the Knowledge Society and fears of those qualities and characteristics of the child that threatens its present and/or future actualization." PISA is an answer in our global society to include every single child, every single 
country in the welfare, but at the same time that includes, it excludes as the results present children and nations hierarchically, by ordering people, schools, and nations. We can say that the numerical results naturalize the differences as they are "detached from their immediate context of production" (Hansen 2015: 211). Rankings operate anonymously classifying people and affecting people's life, for good or for bad. If you are the first ones on the rankings, this is good, but if you are the last ones, this is not. From the Linguistic Turn point of view, language and numbers do not only represent reality, but they also create; categories and measurements can "make up people" (Hacking 1986) in a way of making a person starting feeling (or not) part of a group: the successful or unsuccessful in PISA.

"The numbers of PISA are never merely numbers," (Popkewitz 2011: 38), they constitute reality, they produce subjects, they produce the "self" and the "others," they "forge" the notion of equality, as numbers are considered to be transparent. But the idea of equality through the magnitudes of number elides inequalities, but also produces them as seemingly thrusts for inclusion.

From such ground, the external evaluations, in our point of view, instead of contributing to solve the "well-known" problems in education, they end up camouflaging them and, consequently, naturalizing the differences, as the results are visualized in statistical tables publicized by the media, bringing, when the results are publicized, to a "witch hunting" in our country. This finds echo in Bolivar's study (2011) who undertakes an analysis of PISA from the perspective of the "losers," focusing on Ibero-American countries in which Brazil takes part. He argues that people in Ibero-American countries feel dissatisfied or discontented with the results, which are not good most of the times, as they are presented with a degree of sensationalism. As I said above, the media show them as disgrace for the nation and start looking for the guilty ones, most of the times, the teachers.

However, the rationality of these evaluations is not questioned: to whom they interest; what they camouflage; what kind of subject they are producing in education and in contemporary society.

But what kind of subjects in education do PISA and the external assessments are fabricating? In our view, the future generation of global citizens is transformed into "scientific objects." These tests look at the world in a homogenous way, not seeing the differences, and what is worse, not respecting the differences, like differences in knowledge, for example. A 15-year-old student that does not fit in tests like this is out, out of the real-life situations, out of this intended homogenous world, and out of the future global citizen generation. A nation whose education policy does not adapt itself to the external tests is out, out of the future. This is really what these tests are creating: the National and Educational subjects whose truth can be told in numbers in relation to problem-solving skills, in mathematics, literacy, and science, but to continue the world the way it is, not change it. Is this the world that we want? Or better, what is the world that we want? Every nation (not economy), every school, every teacher should ask and try to answer or, at least, pursue, along their lives, the answer for this question, in an ethical way. Evaluations, tests, internal and external are, as everything in education, a matter of ethics, in Foucault's perspective. The author does not understand ethics as moral philosophy or metaphysical and epistemological investigation, but as a relation of the self to him/herself, called as "modes 
of subjectivation" (mode d'assujettissement), that is, "the way in which the individual establishes his relation to the rule and recognizes himself as obliged to put into practice" (Foucault 1990: 27). Ethics is the exercise of an individual on him/herself when faced to moral recommendations for certain conducts, which constitutes him/ her own moral being. That is the way I see the subjects implied in education as actors of their own history, as inventors, and as living life as a work of art (Foucault 1984).

We hope that this research can destabilize some aspects imbricated in external evaluations, in the traces of the Foucauldian thought of being as "a firework manufacturer," that is, "that it can make advance, it can move forward, that it can make fall the walls" (Foucault 1975). ${ }^{18}$

\section{References}

Bolivar, A. (2011). The dissatisfaction of the losers: PISA public discourse in Ibero-American countries. In M. A. Pereya et al. (Eds.), PISA Under Examination: Changing knowledge, changing tests, and changing schools (pp. 61-74). Netherlands: Sense Publishers.

Chakrabarty, D. (1992). Provincializing Europe: Post Coloniality and the Critique of History. Cultural Studies, 6(3), 337-357.

Foucault, M. (1972). The archaeology of knowledge. New York: Harper \& Row publishers.

Foucault, M. (1975). Entretien avec Roger-Pol Droit. Le Point 01/07/04, No. 1659 p. 82. Retrieved from http://foucault.info/documents/foucault.entretien1975.fr.html.

Foucault, M. (1977a). Truth and power. In Power/knowledge: Selected interviews and other writings. 1972-1977 (pp. 109-133). Random House.

Foucault, M. (1977b). Discipline and Punish: The birth of the prison. London: Penguin.

Foucault, M. (1984). What is Enlightenment? In P. Rabinow (Ed.), The Foucault Reader (pp. 32-50). New York: Pantheon Books.

Foucault, M. (1990). The use of pleasure. In Vol. 2 history of sexuality. Trad. Robert Hurley. New York: Vintage Books Ed.

Foucault, M. (1991). 'Governmentality', trans. Rosi Braidotti and revised by Colin Gordon. In G. Burchell, C. Gordon, \& P. Miller (Eds.), The Foucault effect: Studies in governmentality. Chicago, IL: University of Chicago Press.

Foucault, M. (2000). Truth and power. In J. B. Faubion (Ed.), Essential works of Michel Foucault 1954-1984 (Vol. 13). New York: The New York Press.

Foucault, M. (2008). The Birth of biopolitics. Lectures at the Collège de France. Trans. G. Burchell. Naissance de la biopolitique. Cours au Collège de France. 1978-1979. New York: Palgrave Macmillan.

Gore, J. (1994). In T. Silva (Ed.), Foucault e Educação: Fascinantes Desafios. Vozes: O Sujeito da Educação. Petrópolis.

Hacking, I. (1986). Making up people. In T. C. Heller, M. Sosna, \& D. E. Wellbery (Eds.), Reconstructing Individualism. Autonomy, Individuality and the Self in Western Thought. Stanford, CA: Stanford University Press.

Hacking, I. (1990). The taming of chance. Cambridge: Cambridge University Press.

Hansen, H. K. (2015). Numerical operations, transparency illusions and the datification of governance. European Journal of Social Theory Sage, 18(2), 203-220.

\footnotetext{
${ }^{18}$ My translation from: Je suis un artificier. (...) Je ne suis pas pour la destruction, mais je suis pour qu'on puisse passer, pour qu'on puisse avancer, pour qu'on puisse faire tomber les murs. From http://foucault.info/documents/foucault.entretien1975.fr.html.
} 
Lyotard, J. F. (1984). The post modern condition. In J. C. Alexander \& S. Seidman (Eds.), Culture and society: Contemporary debates. Cambridge: Cambridge University Press.

Mascia, M. A. A. (2003). Investigações Discursivas na Pós-Modernidade. Uma análise das relações de poder-saber do Discurso Político Educacional de Língua Estrangeira. Campinas: Mercado de Letras/FAPESP.

Mascia, M. A. A. (2009). Inclusion or exclusion? An analysis of the Brazilian curriculum discourse of the 1980s and the 1990s. In M. Kontopodis (Ed.), Culture and emerging educational challenges: A dialogue with Brazil/Latin America. Berlin: Lehmanns Media.

Mehta, U. S. (1997). Liberal strategies of exclusion. In Cooper \& Stoler Tensions of Empire. Berkeley, CA: University of California Press.

Open Letter to Andreas Schleicher, OECD, Paris. (2014). 12(7): 872-877. https://doi.org/10.2304/ pfie.2014.12.7.872. Retrieved from: http://journals.sagepub.com/doi/abs/10.2304/pfie.2014.12 .7.872? journalCode=pfea.

Pêcheux, M., \& Fuchs, C. (1975). A propósito da Análise Automática do Discurso. In G. Hak (Ed.), Por uma análise automática do discurso (pp. 163-252). Campinas: Ed. Unicamp.

Pennycook, A. (1994). The Cultural Politics of English as an International Language. New York: Longman.

Popkewitz, T. (2011). PISA-numbers, standardizing conduct, and the alchemy of school subjects. In M. A. Pereya et al. (Eds.), PISA under examination: Changing knowledge, changing tests, and changing schools (pp. 31-46). Netherlands: Sense Publishers.

Popkewitz, T. S. (2013). The impracticality of practical knowledge and lived experience in educational research. In Nordic Studies in Education (Vol. 33, pp. 124-139). Olso: Educational Research on Everyday Life.

Márcia Aparecida Amador Mascia is a professor at the Graduate Program in Education at "Universidade São Francisco" in the state of São Paulo, Brazil. She is the leader of the Brazilian research group "Estudos Foucaultianos e Educação" (Foucaultian Studies and Education), certified by CNPq. She worked as the coordinator of the Graduate Program for 2 years (2012-2013) and has acted as member of many committees. Her approach is based on French Discourse Analysis, Foucault's archaeological and genealogical studies, deconstruction, and psychoanalysis within the broader postmodern social theory. Her research interests are the discourses and the identities in education, especially on curriculum, teachers' education, the teaching-learning of languages, the conflict of oral languages and sign languages for deaf students, the discourses of exclusion and resistance of education, and, more recently, the external assessments, like PISA. Email: marciaaam@uol.com.br.

Open Access This chapter is licensed under the terms of the Creative Commons Attribution 4.0 International License (http://creativecommons.org/licenses/by/4.0/), which permits use, sharing, adaptation, distribution and reproduction in any medium or format, as long as you give appropriate credit to the original author(s) and the source, provide a link to the Creative Commons licence and indicate if changes were made.

The images or other third party material in this chapter are included in the chapter's Creative Commons licence, unless indicated otherwise in a credit line to the material. If material is not included in the chapter's Creative Commons licence and your intended use is not permitted by statutory regulation or exceeds the permitted use, you will need to obtain permission directly from the copyright holder. 